\title{
Capnocytophaga canimorsus: Rare cause of Fatal Septic Shock. Case report
}

Roman Zazula ${ }^{1 *}$, Miroslav Prucha ${ }^{2}$, Michal Moravec $^{1}$ and Frantisek Valeska ${ }^{1}$

${ }^{1}$ Department of Anesthesiology and Intensive Care, First Faculty of Medicine, Charles University in Prague and Thomayer University Hospital, Prague, Czech Republic 2Department of Clinical Biochemistry, Hematology and Immunology, Na Homolce Hospital, Prague, Czech Republic

"Corresponding author: Roman Zazula, Department of Anesthesiology and Intensive Care, First Faculty of Medicine, Charles University in Prague and Thomayer University Hospital, Prague, Czech Republic, Tel: +420261083811; E-mail: roman.zazula@ftn.cz

Received date: March 16, 2015; Accepted date: August 24, 2015; Published date: August 31, 2015

Copyright: ( 2015 Zazula R, et al. This is an open-access article distributed under the terms of the Creative Commons Attribution License, which permits unrestricted use, distribution, and reproduction in any medium, provided the original author and source are credited.

\begin{abstract}
Introduction: Capnocytophaga canimorsus is a common bacterium in oral cavity of dogs and cats. Severe sepsis can develop following a dog or cat bite or scratch in susceptible individuals. Main risk factor for severe infections is immune deficit.

Case presentation: We describe a case of eighty-one-years old woman with significant comorbidities admitted to the hospital with fever and non-specific symptoms following a fall at home. She was bitten by her dog 3 days prior to admission with a small wound on her hand. She had cardiac arrest with cardiopulmonary resuscitation eleven hours after admission and died ten hours later in ICU from refractory septic shock. PCR confirmed C. canimorsus as a causative organism.

Conclusions: Severe infections caused by $C$. canimorsus can develop following a bite or a scratch by dog or cat. Fulminant sepsis with fatal outcome can rapidly evolve and the main risk factor among patient population is present immune deficiency. Clinicians should be aware of this fact and any person at risk presenting to the hospital with recent bite or scratch injury by dog or cat should be given adequate antibiotic treatment.
\end{abstract}

Keywords: Bite-related sepsis; Capnocytophaga canimorsus, Intensive care; Splenectomy; PCR diagnostics

\section{Introduction}

Capnocytophaga canimorsus is bacteria commonly present in oral cavity of dogs and cats. Transmission to human is possible following a bite or a scratch by the animal, wound can be sometimes negligible and resulting infection often underestimated [1-3]. Especially immunocompromised patients and patients with severe comorbidities are susceptible to develop severe sepsis/septic shock not infrequently with fatal outcome.

C. canimorsus is sensitive to penicillins, $3^{\text {rd }}$ generation cephalosporins, carbapenems, tetracyclins, chinolons, clindamycin, rifampicin and linezolid. It is resistant to aztreonam, aminoglycosides and trimethoprim-sulphametoxazol [4].

It was suggested to treat prophylactically with appropriate antibiotics all immunocompromised patients following dog or cat bite or after the contact of open wound with animal saliva. For healthy subjects the administration of antibiotic prophylaxis remains controversial [1].

\section{Case Presentation}

Eighty-one-years old woman with extensive medical history was admitted to the department of medicine of teaching hospital following a fall causing worsening of her chronic back pain. On admission, she reported nausea and general malaise as the reason for her fall; she also mentioned she had been bitten in the hand by her pet dog at home three days ago. The wound was tender, but she nursed it with just external cooling, currently experiencing only mild pain in the wound area.

Her past medical history included hypertension, cardiac pacemaker implanted for sick sinus syndrome, she had chemotherapy for B-nonHodgkin small lympholytic lymphoma involving the mediastinum and the right orbit, currently in remission. The patient's other medical history included splenectomy, cholecystectomy, thyroidectomy for goiter, toxoplasmosis, she was treated for suspected borreliosis. She suffered with arthritis of the hip and knee; severe osteoporosis with multiple compression fractures of thoracic and lumbar vertebrae, impaired spinal posture, and multilevel stenosis of the spinal canal.

At the time of admission to medical ward at 7:30 pm, the patient had stable vital signs, fever $\left(38.1^{\circ} \mathrm{C}\right)$, she was dehydrated, further physical examination revealed no pathology except for marked spine tenderness on percussion and tiny, reddish spots in the interdigital webbing between the first and the second finger of her left hand, where she was bitten.

Laboratory examination on admission showed moderate renal and liver dysfunction (creatinine $202 \mu \mathrm{mol} / \mathrm{l}$, AST 1,28 $\mu \mathrm{kat} / \mathrm{l}$, ALT 0,65 $\mu \mathrm{kat} / \mathrm{l}$, GMT $6,11 \mu \mathrm{kat} / \mathrm{l}$, INR 1,3), slightly raised CRP and elevated levels of troponin, CK and myoglobin (Table 1). At this point, no definitive diagnosis was made and she received general supportive measures. 
Citation: Zazula R, Prucha M, Moravec M, Valeska F (2015) Capnocytophaga canimorsus: Rare cause of Fatal Septic Shock. Case report. Clin Microbiol 4: 217. doi:10.4172/2327-5073.1000217

Page 2 of 4

\begin{tabular}{|c|c|c|c|}
\hline & Admission to medical ward & Admission to ICU & Normal value \\
\hline WBC & $4.0 \times 10^{9} \mathrm{cells} / \mathrm{l}$ & $3.0 \times 10^{9} \mathrm{cells} / \mathrm{l}$ & $4.0 \times 10^{9}-10.0 \times 10^{9} \mathrm{cells} / \mathrm{l}$ \\
\hline ERY & $3.00 \times 10^{12} \mathrm{cells} / \mathrm{l}$ & $2.7 \times 10^{9} \mathrm{cells} / \mathrm{l}$ & $3.8 \times 10^{12}-5.2 \times 10^{12} \mathrm{cells} / \mathrm{l}$ \\
\hline $\mathrm{Hb}$ & $101 \mathrm{~g} / \mathrm{l}$ & $96 \mathrm{~g} / \mathrm{l}$ & $120 \mathrm{~g} / \mathrm{l}-160 \mathrm{~g} / \mathrm{l}$ \\
\hline HTC & 0.31 & 0.29 & $0.35-0.47$ \\
\hline PLT & $117 \times 10^{9} \mathrm{cells} / \mathrm{l}$ & $61 \times 10^{9}$ cells $/ \mathrm{l}$ & $50 \times 10^{9}-400 \times 10^{9} \mathrm{cells} / \mathrm{l}$ \\
\hline PT - INR & 1.30 & 2.84 & $0.9-1.2$ \\
\hline aPTT & & $>180 \mathrm{~s}$ & $33.5 \mathrm{~s}$ \\
\hline D-dimers & & $>4000 \mathrm{ng} / \mathrm{ml}$ & $0 \mathrm{ng} / \mathrm{ml}-500 \mathrm{ng} / \mathrm{ml}$ \\
\hline pUrea & $12.7 \mathrm{mmol} / \mathrm{l}$ & $15.3 \mathrm{mmol} / \mathrm{l}$ & $3.2 \mathrm{mmol} / \mathrm{l}-10 \mathrm{mmol} / \mathrm{l}$ \\
\hline pCreatinin & $202 \mu \mathrm{mol} / \mathrm{l}$ & $274 \mu \mathrm{mol} / \mathrm{l}$ & $40 \mu \mathrm{mol} / \mathrm{l}-110 \mu \mathrm{mol} / \mathrm{l}$ \\
\hline pBilirubin & $5.0 \mu \mathrm{mol} / \mathrm{l}$ & $3.0 \mu \mathrm{mol} / \mathrm{l}$ & $5 \mu \mathrm{mol} / 1-20 \mu \mathrm{mol} / \mathrm{l}$ \\
\hline pAST & $1.28 \mu \mathrm{kat} / \mathrm{l}$ & $3.2 \mu \mathrm{kat} / \mathrm{l}$ & $0.20 \mu \mathrm{kat} / \mathrm{l}-0.55 \mu \mathrm{kat} / \mathrm{l}$ \\
\hline pALT & $0.65 \mu \mathrm{kat} / \mathrm{l}$ & $1.12 \mu \mathrm{kat} / \mathrm{l}$ & $0.20 \mu \mathrm{kat} / \mathrm{l}-0.50 \mu \mathrm{kat} / \mathrm{l}$ \\
\hline pGMT & $6.11 \mu \mathrm{kat} / \mathrm{l}$ & $4.99 \mu \mathrm{kat} / \mathrm{l}$ & $0.10 \mu \mathrm{kat} / \mathrm{l}-0.70 \mu \mathrm{kat} / \mathrm{l}$ \\
\hline pALP & 1.9 ukat/l & $1.9 \mu \mathrm{kat} / \mathrm{l}$ & $0.6 \mu \mathrm{kat} / \mathrm{l}-2.70 \mu \mathrm{kat} / \mathrm{l}$ \\
\hline pAMS & $0.76 \mu \mathrm{kat} / \mathrm{l}$ & $2.87 \mu \mathrm{kat} / \mathrm{l}$ & $0.22 \mu \mathrm{kat} / \mathrm{l}-0.88 \mu \mathrm{kat} / \mathrm{l}$ \\
\hline pAlbumin & & $26.7 \mathrm{~g} / \mathrm{l}$ & $35 \mathrm{~g} / \mathrm{l}-44 \mathrm{~g} / \mathrm{l}$ \\
\hline pCK & $5.47 \mu \mathrm{kat} / \mathrm{l}$ & & $0.50 \mu \mathrm{kat} / \mathrm{l}-2.4 \mu \mathrm{kat} / \mathrm{l}$ \\
\hline $\mathrm{sNa}$ & $138 \mathrm{mmol} / \mathrm{l}$ & $136 \mathrm{mmol} / \mathrm{l}$ & $137 \mathrm{mmol} / \mathrm{l}-144 \mathrm{mmol} / \mathrm{l}$ \\
\hline sk & $3.7 \mathrm{mmol} / \mathrm{l}$ & $5.0 \mathrm{mmol} / \mathrm{l}$ & $3.6 \mathrm{mmol} / \mathrm{l}-4.9 \mathrm{mmol} / \mathrm{l}$ \\
\hline $\mathrm{sCl}$ & $101 \mathrm{mmol} / \mathrm{l}$ & $111 \mathrm{mmol} / \mathrm{l}$ & $97 \mathrm{mmol} / \mathrm{l}-108 \mathrm{mmol} / \mathrm{l}$ \\
\hline pGlucose & $6.2 \mathrm{mmol} / \mathrm{l}$ & $7.3 \mathrm{mmol} / \mathrm{l}$ & $4.0 \mathrm{mmol} / 1-6.8 \mathrm{mmol} / \mathrm{l}$ \\
\hline pCRP & $50.4 \mathrm{mg} / \mathrm{l}$ & $119 \mathrm{mg} / \mathrm{l}$ & $0 \mathrm{mg} / \mathrm{l}-5 \mathrm{mg} / \mathrm{l}$ \\
\hline pProcalcitonin & & $96.8 \mu \mathrm{g} / 1$ & $0.05 \mu \mathrm{g} / \mathrm{l}-0.5 \mu \mathrm{g} / \mathrm{l}$ \\
\hline hsTnT & $76.2 \mathrm{ng} / \mathrm{l}$ & $120 \mathrm{ng} / \mathrm{l}$ & $0 \mathrm{ng} / \mathrm{l}-14 \mathrm{ng} / \mathrm{l}$ \\
\hline pNT-proBNP & & $19176 \mathrm{ng} / \mathrm{l}$ & $0 \mathrm{ng} / \mathrm{l}-150 \mathrm{ng} / \mathrm{l}$ \\
\hline pMyoglobin & $2446 \mu g / l$ & & $25 \mu \mathrm{g} / \mathrm{l}-58 \mu \mathrm{g} / \mathrm{l}$ \\
\hline
\end{tabular}

Table 1: Laboratory values during course of illness.

On day 2 of her hospital stay she talked to her nurse at 5:40 am; several minutes later, the patient had cardiac arrest, ECG showed asystole with pacing spikes. Cardiopulmonary resuscitation was immediately started, patient was intubated and her circulation was successfully restored after 15 minutes. The patient was transferred to the Intensive Care Unit for ongoing care.

On admission to the ICU at 6:20 am: the patient was unconscious with preserved brain stem reflexes, equal slowly responding pupils. Afebrile $-36.3^{\circ} \mathrm{C}$, with cyanosis and a mottling of the trunk and lower limbs, cold peripheries and signs of hypovolemia. She was in circulatory shock, blood pressure $120 / 55 \mathrm{mmHg}$ on noradrenaline at a dose of $0,20 \mu \mathrm{g} / \mathrm{kg} / \mathrm{min}$; ECG showed alternating sinus rhythm and paced rhythm with wide complexes $80 / \mathrm{min}$. Her abdomen was distended, but soft with no bowel sounds, she was anuric. Laboratory investigation changed dramatically and was consistent with severe sepsis/septic shock with multiorgan dysfunction, procalcitonin level was remarkably elevated to $96.8 \mathrm{ng} / \mathrm{ml}$ (Table 1 ).

Microscopic examination of peripheral blood smears requested for differential blood count processed by May-Grünwald Giemsa stain revealed the presence of bacterial rods (Figure 1). 


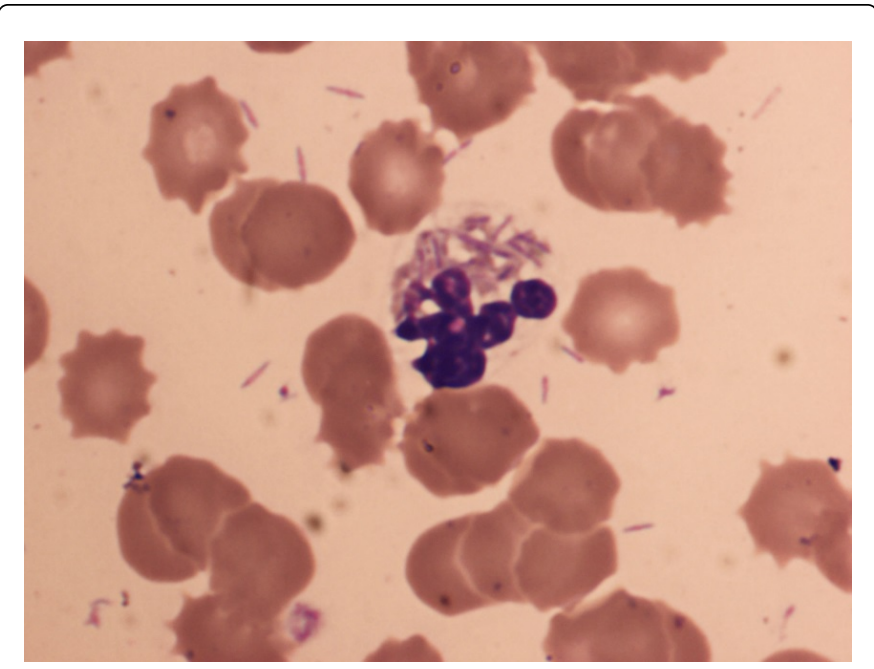

Figure 1: Peripheral blood smear showing rods-Capnocytophaga canimorsus (May-Grünwald Giemsa stain).

Given the suspected infectious etiology and the clinical picture, the patient's blood was drawn for blood culture and PCR diagnosis of the potential pathogens; while empirical broad-spectrum antibiotic therapy (imipenem/cilastatin+metronidazole) was initiated. The patient received aggressive fluid resuscitation with high dose vasopressor support and stress dose steroids replacement. Imaging studies: chest X-ray, abdominal US, transthoracic echocardiography did not show the obvious source of infection, making us to consider urinary tract infection or mesenterial ischemia as a probable cause of sepsis. Progressive multiorgan failure was resistant to resuscitation therapy and the patient died at $4 \mathrm{pm}$ on the same day with the clinical diagnosis of refractory septic shock.

The suspected infectious etiology of the shock was confirmed by the detection of the pathogen in a blood sample using sequencing of the $16 \mathrm{~S}$ rRNA and 18S rRNA genes and identifying Capnocytophaga canimorsus in the load of $6.141,239$ genome equivalents $/ \mathrm{ml}$ of blood sample. The laboratory results were received due to the processing of the sample and the detection time several hours after the patient had died. The two aerobic and anaerobic blood cultures using conventional microbiological techniques were negative.

\section{Discussion}

Capnocytophaga canimorsus is commensal bacteria frequently found in oral cavity of dogs and cats. Van Dam et al. reported PCR detection of C. canimorsus in $74 \%$ of tested dogs [5].

It is capnophilic, facultatively anaerobic, Gram negative bacillus capable of fusiform movement. Biochemical profile is characterized by positive reaction to oxidase, catalase, O-nitrofenyl-beta-Dgalactosidase and arginine hydroxylase and negative reaction to urease, indol and nitrate. Capnocytophaga species are regarded difficult to culture because of its specific requirements for nutrients including higher iron and carbon dioxide levels. C. canimorsus was routinely grown on Heart Infusion Agar (Difco) supplemented with $5 \%$ sheep blood (Oxoid) for 2 days at $37^{\circ} \mathrm{C}$ in an incubator containing $5 \% \mathrm{CO}_{2}$. Often, the organism cannot be detected by standard laboratory methods $[6,7]$.
Sepsis caused by $C$. canimorsus following dog and cat bite or scratch is uncommon. The risk group for developing septic syndrome are immunocompromised patients, i.e. patients receiving cytotoxic or biological drugs, patients with HIV, hematological malignancies, transplant recipients and patients with multiple severe comorbidities causing the immune deficiency, i.e. patients with chronic alcohol use, cirrhosis, malnutrition and post splenectomy. These patients should be prophylactically treated with penicillins with beta lactamase inhibitor [3,8-12]. However, no identifiable risk factor was found in $40 \%$ of cases of sepsis caused by C. canimorsus [1,2].

Perhaps the largest set of diagnosed cases with $C$. canimorsus infection was reported by Janda et al. reviewing 56 human $C$. canimorsus isolates detected between 1972 and 2004 in a reference laboratory in California [13]. The study suggested a standard microbiological laboratory is unable properly isolate and identify $C$. canimorsus. In clinical terms, infection with this microbe in the reported set of patients resulted in sepsis and/or septic shock in $41 \%$ of cases [14]. Some cases of fulminant severe sepsis due to $C$. canimorsus infection after dog bite who died less than 12 hours after admission, were reported. Such cases are often not caused by gross injury but by benign bites $[2,14]$.

The bite-related septic syndrome caused by dogs or cats is still often missed or underestimated in current clinical practice. Patient's recent medical history involving pet bite needs to be always noted and put in the appropriate perspective while assessing the patient on admission and making differential diagnosis.

In our case, elderly patient with immunodeficiency-history of splenectomy and hematological malignancy, presenting with fever, recently bitten by her dog and apparent, though minor injury on her hand was not recognized as being infected in the differential diagnosis on admission. It is common, that infection and sepsis can present with non-specific and mild symptoms in some subgroup of patients, and elderly and immunocompromised patients being the typical population for this kind of "vague" manifestation of established infection/sepsis. Resulting development of severe sepsis and septic shock may in these patients take hyper acute course, often with fatal outcome despite high level of supportive care.

All major studies and guidelines for the management of sepsis have highlighted the need for timely and appropriate administration of antibiotic therapy having a critical impact on patient survival [15-17]. Our patient was diagnosed and treated for severe sepsis with significant delay, which may have contributed to unfavorable outcome. Moreover, although the patient was treated with appropriate antibiotics following admission to ICU, the dog bite was never considered to be clinically significant. We were aware of the findings of bacterial rods in the peripheral blood smear, but the identified bacteria- $C$. canimorsus, was unexpected and to a certain extent, unknown, species to the ICU physicians treating the patient.

PCR diagnostics provided clear and robust evidence of causative organism, which wouldn't be identified by using standard laboratory methods. Therefore we believe it represents useful and rapid tool for pathogen detection in selected cases of sepsis with diagnostic conundrum.

\section{Conclusion}

Human infections caused by Capnocytophaga canimorsus can develop following a bite or a scratch by dog or cat. Severe fulminant 
sepsis with fatal outcome is not uncommon; the main risk factor among patient population is present immune deficiency. Clinicians should be aware of this fact and any person at risk presenting to hospital with recent bite or scratch injury by dog or cat should be given adequate antibiotic treatment.

C. canimorsus can escape detection with standard laboratory cultures and PCR seems to be useful and rapid tool to identify causative species of such infections.

\section{References}

1. Gaastra W, Lipman LJ (2010) Capnocytophaga canimorsus. Vet Microbiol 140: 339-346.

2. Lion C, Escande F, Burdin JC (1996) Capnocytophaga canimorsus infections in human: Review of the literature and cases report. Eur Epidemiol 12: 523-533.

3. Rossi P, Oger A, Bagneres D, Frances Y, Granel B (2009) Capnocytophaga canimorsus septicaemia in an asplenic patient with systemic lupus erythematosus. BMJ Case Rep.

4. Hore C (2001) Important unusual infections in Australia: a critical perspective. Crit Care Resusc 3:262-272.

5. van Dam AP, van Weert A, Harmanus C, Hovius KE, Claas EC, et al (2009) Molecular characterization of Capnocytophaga canimorsus and other canine Capnocytophaga spp. and assessment by PCR of their frequencies in dogs. J Clin Microbiol 47: 3218-25.

6. Low SCH, Greenwood JE (2008) Capnocytophaga canimorsus: infection, septicaemia, recovery and reconstruction. Journal of Medical Microbiology 57: 901-903.

7. Shin H, Mally M, Kuhn M, Paroz C, Cornelis GR (2007) Escape from immune Surveillance by Capnocytophaga canimorsus. The Journal of infectious Diseases 195:375-86.
8. Rougemont M, Ratib O, Wintsch J, Schrenzel J, Hirschel B (2013) Capnocytophaga canimorsus prosthetic aortitis in an HIV-positive woman. J Clin Microbiol 51: 2769-71.

9. Sarma PS, Mohanty S (2001) Capnocytophaga cynodegmi cellulitis, bacteremia and pneumonitis in a diabetic man. J Clin Microbiol 39: 2028-9.

10. Shahani L, Khardori N (2014) Overwhelming Capnocytophaga canimorsus infection in a patient with asplenia. BMJ Case Rep 23: 2014.

11. Pokroy-Shapira E, Shiber S, Molad Y (2012) Capnocytophaga bacteraemia following rituximab treatment. BMJ Case Rep doi:10.1136/ bcr-2012-006224.

12. Jolivet-Gougeon A, Sixou JL, Tamanai-Shacoori Z, Bonnaure-Mallet M (2007) Antimicrobial treatment of Capnocytophaga infections. Int J Antimicrob Agents 29: 367-373.

13. J. Michael Janda, Margot H. Graves, David Lindquist, and Will S. Probert (2006) Diagnosing Capnocytophaga canimorsus Infections. Emerg Infect Dis. 12(2): 340-342.

14. Ota K, Kazawa T, Tsubata C, Suzuki M, Imaoka K (2009) An autory case involving severe sepsis due to Capnocytophaga canimorsus infection. Kansenshogaku Zasshi 83: 661-4.

15. Kumar A, Roberts D, Wood KE, Light B, Parrillo JE, et al. (2006) Duration of hypotension before intitiation of effective antimicrobial therapy is the critical determinant of survival in human septic shock. Crit Care Med. 34(6): 1589-96.

16. Cummings $P$ (1994) Antibiotics to prevent infection in patients with dog bite wounds: a meta analysis of randomized trials. Ann Emerg Med. 23: 335-40.

17. Hloch O, Mokra D, Masopust J, Hasa J, Charvat J (2014) Antibiotic treatment following a dog bite in an ammunocompromized patient in order to prevent Capnocytophaga canimorsus infection: a case report. BMC Res Notes 7:432. 